\title{
Article \\ Employee Recognition, Task Performance, and OCB: Mediated and Moderated by Pride
}

\author{
Tianfei Yang ${ }^{1}$, Xia Jiang ${ }^{2, *}$ and Huan Cheng ${ }^{3}$ (1) \\ 1 School of Economics and Management, Wuhan University, Wuhan 430072, China; faye_yang@whu.edu.cn \\ 2 College of Economics and Management, China-Africa International Business School, \\ Zhejiang Normal University, Jinhua 321004, China \\ 3 School of Management, Huazhong University of Science and Technology, Wuhan 430074, China; \\ chenghuan@whut.edu.cn \\ * Correspondence: jiangxia@zjnu.edu.cn
}

Citation: Yang, T.; Jiang, X.; Cheng, H. Employee Recognition, Task

Performance, and OCB: Mediated and Moderated by Pride.

Sustainability 2022, 14, 1631. https:// doi.org/10.3390/su14031631

Academic Editor: Huseyin Arasli

Received: 11 January 2022

Accepted: 26 January 2022

Published: 30 January 2022

Publisher's Note: MDPI stays neutral with regard to jurisdictional claims in published maps and institutional affiliations.

Copyright: (C) 2022 by the authors. Licensee MDPI, Basel, Switzerland. This article is an open access article distributed under the terms and conditions of the Creative Commons Attribution (CC BY) license (https:// creativecommons.org/licenses/by/ $4.0 /)$.

\begin{abstract}
Employee recognition, an incentive approach often used in management practice, plays an important role in organizations. In comparison to other incentive methods, employee recognition does not focus on the amount of money and material, but it does recognize employees and their achievements and values in the workplace. We would like to reveal the outcome and emotional mechanism of employee recognition in this work. Based on the broaden-and-build theory, we explored the role of the emotion pride on the relationship between employee recognition with task performance and OCB. Using a cross-section sampling approach, 256 valid questionnaires from 58 groups by the leader-member dyad method were collected. SPSS20.0 and Amos21.0 were used to perform the data analysis and verify the hypothesis. The results showed that: (1) Employee recognition has a significantly positive effect on task performance and OCB. (2) Authentic pride mediates the relationship between employee recognition with (a) task performance and (b) OCB. (3) Hubristic pride positively moderates the relationship between employee recognition with (a) task performance and (b) OCB. In conclusion, this study reveals the emotional response and behavioral results of employee recognition by focusing on the role of pride in the path of employee recognition with task performance and OCB.
\end{abstract}

Keywords: employee recognition; pride; task performance; organizational citizenship behavior

\section{Introduction}

Recognizing and rewarding employees is a common approach to achieve leadership effectiveness in contemporary organizational management [1]. Researchers point out that employee recognition is an important vehicle for motivation [2,3]. Supervisors can reward and recognize individuals or teams formally or informally, in public or private, by material or non-material means [4], such as "a pat on the back", "personally congratulating for a job well done", and "publicly recognizing for good performance" [1]. Although there are many ways to express employee recognition, one common feature is that it conveys to employees that their value at work is recognized [5].

Workplace recognition may come from colleagues, subordinates, and supervisors [4]. In this study, we focus on the recognition of superiors in particular, which we believe is very important because it can guide employees to understand whether the organization recognizes their value [6]. In fact, because of the authority of their superiors and the particularity of their positions, they are empowered to provide recognition to employees and to recognize the contributions that individuals have made to the organization [7]. The affective event theory holds that the events experienced by employees at work will affect their emotional state, and then affect their work attitude and work behavior. Previous studies have made many findings on the relationship between employee recognition and work attitude and behaviors. Studies have pointed out that the time spent by superiors 
to provide recognition can increase employees' trust in the organization and perceive the organization's support [8], improve job satisfaction, and thus improve job performance. In comparison with rewards, employee recognition is more non-monetary related, so it can inspire employees to do more work at a very low cost [1]. Therefore, most recognition studies focus on in-role performance [9]. In this study, we choose OCB as an outcome variable besides task performance to further enrich the gaps in relevant literature by examining how recognition practices (non-financial incentives) provided by superiors influence employees of their in-role and extra-role outcomes, which is task performance and OCB, in our study.

However, besides the fruitful part on work attitude and behaviors, little attention has been paid to the emotional reaction to employee recognition. The recognition from leaders is a great encouragement to employees. Results have found that performance appraisal makes employees feel achievement, gain more confidence, and triggers a positive psychological response [3]. Emotion, caused by a specific object or cause, usually includes a series of physiological reactions and behavioral consequences, which are relatively intense but last for a short time [10]. Pride, as a common self-conscious experience [11], is a typical emotion regulating human social interaction, both from the micro level of individual interaction and the macro level of social interaction [12]. Related studies have demonstrated that pride will influence regulation of the sequent behaviors, and is closely associated with self-efficacy, job satisfaction, goal success, and work performance, which decreases turnover intentions $[13,14]$.

Pride is a positive, subjective emotional experience when an individual attributes a successful event or a positive event to the result of their ability or effort [15]. In prior research, a series of studies demonstrated that pride is composed of two distinct and largely independent facets: authentic pride and hubristic pride [16,17]. These two facets both constitute the rich connotation of pride. Authentic pride is reliably associated with feelings of confidence, self-worth, productivity, and achievement. Hubristic pride is reliably associated with arrogance, egotism, and conceit [18]. Therefore, the second goal of our study is to explore the dual role of pride in the workplace.

In conclusion, our study aims to explore the pathway of employee recognition on task performance and $\mathrm{OCB}$, which broadens the recognition literature by both considering employees in-role and extra-role reactions. What's more, the pride emotion adopted into the model plays two different roles because of its duality. Integrating pride into the model framework to explore how superior recognition affects task performance and OCB could enrich the current knowledge, both in the recognition study and emotion, but especially pride study. In addition, the integrated model is closer to the real organizational management situation, which is much more helpful and meaningful.

\section{Theory and Hypothesis}

Pride in the workplace is not a rare concept. It has been proved that prideful employees are likely to have a better performance and make creative achievements [19]. Existing studies have confirmed that each distinct dimension is correlated with different personality traits, functions in various roles, and has unique outcomes [20]. In this study, we adopt this research result and follow the path that two-facet pride functions are two different roles. According to the connotation of pride, pride emotion arises from the inner attribution of a successful event or a positive event to the result of one's own ability or effort. In the workplace, task performance directly shows how well the employee does their job, and OCB shows the performance out of the job duty and responsibility, both of which are important outcomes contributing to the organization. When employees are recognized by their leaders, the emotional reaction and followed consequences occur. This study tries to figure out the interaction of leader behavior and employee emotion, to see how pride works in the path between employee recognition and task performance and OCBs (see Figure 1). 


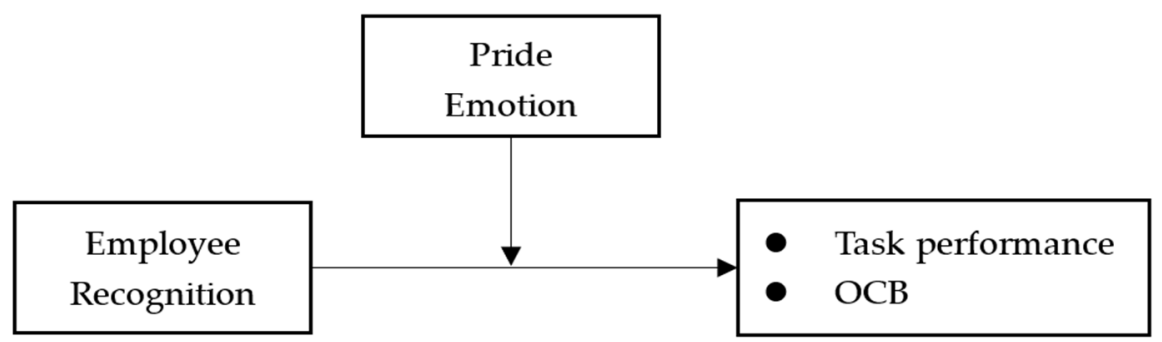

Figure 1. As proposed above, the research model is shown.

\subsection{Employee Recognition with Task Performance and $O C B$}

Generally speaking, employee recognition is a constructive feedback behavior adopted by the leader based on the value judgment of individual employees, including work performance, work investment, and dedication [4]. Studies have confirmed that there was a positive correlation between employee recognition and many positive outcomes of the organization [21]. Existing papers have shown that leaders' recognition and performance appraisal are positively related to satisfaction, fairness, perceived utility, and perceived accuracy [22,23]. When employees are recognized by leaders, employees often feel that leadership is fair and just, which is regarded as a manifestation of organizational justice [24]. Leaders or direct managers show respect to employees, to their performance, and to their value and significance, which could make employees feel psychological safety and a sense of belonging $[25,26]$. Also, positive feedback to employees could stimulate their confidence, help tap their full potential, and bring about a stronger motivation to improve $[3,27]$. While employees get recognized, they have the disposition to perceive organizational support for the use of their strengths [28], which stimulates their work enthusiasm and passion. This feedback largely influences employees and gives them specific guides that are desired by the organization. The recognized employees will be willing to and able to pay more effort to engage in the tasks, improving their work efficiency and performance [29].

Besides the in-role performance, there are some behaviors that generally go beyond the employee's job duty and are not clearly and directly regulated by the normal compensation system, which is defined as organizational citizenship behaviors (OCB). Employee recognition, as an effective feedback behavior, could make employees feel the communication and interaction with leaders, and make employees understand their job responsibilities and roles, so as to improve the quality of trust and relationship with leaders, help employees better integrate into the organization, and perceive organizational support [30]. Therefore, they would like to give back the appreciation of leaders, such as helping colleges, retaining loyalty to the organization, showing proactive behavior, etc. [31]. In this process of benign interaction, employees will be willing to participate in work more actively, and the more they are engaged, the more they would perform OCB [32,33].

Thus, we hypothesize:

Hypothesis 1 (H1). Employee recognition is positively related to task performance and OCB.

\subsection{Pride Emotion: The Mediation and Moderated Mediation}

Pride is a common emotional experience that could affect downstream reactions and behaviors [34], such as, job satisfaction [35] and externally visible behaviors [36]. Pride has a strong incentive effect, especially in the face of setbacks and adversities, which makes employees willing to "overcome" the negative situations at work, improving task performance and helping organizations to achieve goals [37,38]. Also, it is proved that pride encourages employees to establish strong ties with organizations [13]. Thus, it can be seen that pride emotion in the workplace is an important topic.

Authentic pride is related to feelings of controllable, effort-driven achievement [18]. When employees get recognized, regardless of the type of recognition, their success gets acknowledged, which makes them feel confident, ambitious, and honored. This is an entirely 
authentic pride experience. The fundamental foothold of employee recognition lies in the employees themselves. To recognize the employees themselves is to affirm the employees themselves; to recognize the employees' work behavior is to affirm the employees' way of doing things; to recognize the employees' work results is to affirm the employees' work ability; to recognize the employees' work dedication is to affirm the employees' work spirit and work attitude. Therefore, the leader's praise to the employees can help stimulate the employees' self-awareness and make them feel good about themselves. Experiencing pride will make people willing to pay more efforts to practice and learn, as well as to try their best to achieve the set goals [39]. Besides, treating employees with care and respect can make them perceive organizational virtuousness, thus making employees identify with their organization and be proud. In return, they become more willing to do some out-role behaviors to benefit the organization [40].

As a typical positive self-awareness emotion [15], when individuals experience pride, their self-awareness tends to be positive, they have a better sense of self-efficacy, they believe in themselves more, and they recognize their abilities and choices. As pointed out by the broaden-and-build theory of positive emotions, when an individual's positive emotions are high, he or she can face the external environment with a more open and flexible cognitive attitude, make use of more information from the outside world, and think about more possibilities of action, so as to adopt creative ways to deal with work and solve problems $[41,42]$. When employees are recognized by the leader or organization and generate pride, one is to expand the instant thinking sequence to activate the cognitive ability of work; the other is to build the employee's psychological, physical, intellectual, and social resources, help employees to better engage in organizational tasks and improve workplace behaviors [43]. That is to say, being proud could enable them to have more ability and willingness to work harder and to do something beneficial to the organization.

Hypothesis 2 (H2). Authentic pride mediates the relationship between employee recognition with (a)task performance and (b)OCB.

The other facet of pride is hubristic pride, which is narcissistic, self-aggrandizement, and self-enhancement [18]. Leaders' confirmation, respect, and appraisal bring confidence and fulfillment to employees [25,44]. When employees experience high hubristic pride, they will attribute this success more to their own personal ability and personal value. While such employees are recognized, they are often able to better exert their positive emotions to expand resources and build resources, and face work more confidently, are more active in completing job tasks, more willing to help colleagues, show better social adaptability, and can cope with various situations in the workplace with ease [45]. It is the nature of hubristic pride to expand, strengthen, and improve themselves.

People who are in high hubristic pride are usually narcissistic; they want to be praised and respected. When this demand is met, their positive self-evaluation will be confirmed. The study found that pride experience is closely related to the control of subsequent behaviors. Recognition makes them feel achievement and pride. Appraisal information concerning personal agency (e.g., "This was my achievement, not someone else's achievement") can be used to make positive inferences about one's progress toward self-regulation [46]. At this time, they will be more satisfied with the leader and the organization. They will double show their ability, take responsibility for their work, and actively interact with colleagues to convey this information and exert their influence. Proud employees will have more of a sense of social responsibility and higher commitment to the organization [38]. Experiencing pride can help individuals make positive judgments on self-concept, so as to strengthen self-regulation, which helps employees handle their work with full confidence. Therefore, when actively completing their work tasks, they will show more pro-social behaviors to help and support colleagues and teams.

Thus, we hypothesize: 
Hypothesis 3 (H3). Hubristic pride positively moderates the relationship between employee recognition with (a)task performance and (b)OCB.

\section{Method}

\subsection{Sample and Procedure}

This study used a cross-sectional, random sampling method for data collection. Specifically, we invited leaders and their volunteer employees to participate in our study with the help of friends and colleagues. Each leader randomly selected three to five employees in the team to participate. The participants must have a full-time job and been working in the current team for over six months. Leaders were asked to give each employee who would participate a unique code name, and employees were asked to write down their code on their respective questionnaires. We sent paper questionnaires in envelopes to participants by express mail, and the completed questionnaires in sealed envelopes were also sent to us by express mail. For participants who felt using paper questionnaires was inconvenient, questionnaires were sent by email.

The questionnaire is divided into a leadership questionnaire and employee questionnaire. Leaders are invited to evaluate their employees' work performance and organizational citizenship behavior. Three to five employees in the leadership team are invited to evaluate their pride and leader's recognition behavior. The employees were randomly selected by their direct leader. The leader-member dyad method could help to avoid common method bias.

To adapt to China's cultural context, we first translated the original English version questionnaire into the Chinese version, and then we invited a professional to translate the Chinese version back to the English version. After that we compared the translated one to the original one, modifying inappropriate items. Finally, we got the proper Chinese version used in this study.

Samples were collected in many cities along the eastern coast and central China. Finally, 400 questionnaires were issued, and 337 were collected from the finance, real estate, manufacturing, and construction industries. After sorting out and screening the questionnaire, the invalid questionnaires, such as those with missing items, poor filling quality, and were unable to match, were eliminated. A total of 268 valid questionnaires were obtained, and the actual effective recovery rate was $79.53 \%$.

\subsection{Measurement}

The scales we adopted in this study are all very classical and widely used. They were developed by experts and published in high quality academic journals. The reliability and validity have been verified by many scholars.

Employee Recognition. Employee recognition was measured by five items from the contingency reward leadership behavior scale of Walumbwa (2008) [47] and Waldman (1990) [48]. Due to the limitations of existing research, the development of employeeapproved scales is not mature. In the existing research, some scholars manipulate the variable of employee recognition through experiments, and some researchers use interviews. We used the widely accepted Brun and Dugas (2008) [4] concept of employee recognition, which refers to the measurement methods of other similar concepts and borrows the relevant items of employee recognition behavior in the contingency reward leadership behavior scale. The scale has 5 items $(\alpha=0.88)$ using the Likert five-point scale to measure, and the score ranges from 1 to 5 , which means "never" to "always".

Pride. The pride measurement scale was developed by Tracy and Robbins (2007) [15], containing two dimensions: seven items each for authentic pride $(\alpha=0.81)$ and hubristic pride $(\alpha=0.91)$. The scale is measured by the Likert seven-point scale. The score is from 1 to 7 , which means "strongly disagree" to "strongly agree".

Task performance. Task performance refers to performance indicators that are directly related to work output and can directly evaluate the work results. It is closely related to specific job content, but also with the individual's ability, proficiency in completing tasks, 
and work knowledge. To measure task performance, this study used the scale developed by Methot (2015) [49]. There are five items $(\alpha=0.84)$, which are measured by the Likert sevenpoint scale. The score is from 1 to 7 , which means "strongly disagree" to "stronglyagree".

Organizational citizenship behavior. In this study, we used the OCB scale developed by Bachrach (2007) [50], a total of 10 items $(\alpha=0.86)$, using Likert seven-point scale measurement, the score was from 1 to 7 , indicating "strongly disagree" to "stronglyagree".

\subsection{Analytical Strategy}

To the data analysis and hypotheses testing, SPSS 20.0 and Amoss 21.0. were used. Firstly, we calculated the Cronbach's $\alpha$ and factor loadings to measure the reliability and validity of the scale. To present the total items used in the study, and the reliability and validity of the scale, Table 1 shows all the factor loadings, S.E., and Est./S.E. with corresponding $p$-values. Then we made a descriptive statistical analysis to present the basic information of the sample. Before hypothesis testing, Means, SDs, and intercorrelations among study variables were calculated to show the basic relationship among variables. Also, to verify the significance of the research variables, we conducted a confirmatory factor analysis (CFA) on the model using Amoss 21.0.

Table 1. Survey Items.

\begin{tabular}{|c|c|c|c|c|}
\hline Variable & Item & $\begin{array}{l}\text { Standardized } \\
\text { Estimated }\end{array}$ & $\begin{array}{l}\text { Standard } \\
\text { Errors }\end{array}$ & Z (Est./S.E.) \\
\hline \multirow{5}{*}{$\begin{array}{c}\text { Employee } \\
\text { Recognition } \\
(\alpha=0.88, p<0.001)\end{array}$} & $\begin{array}{l}\text { 1. My leader talks about excellent employees, } \\
\text { and they will get extra praise and } \\
\text { recommendation. }\end{array}$ & 0.75 & 0.06 & 13.68 \\
\hline & $\begin{array}{l}\text { 2. When an employee works well, my leader } \\
\text { praises him/her personally. }\end{array}$ & 0.80 & 0.06 & 14.88 \\
\hline & $\begin{array}{l}\text { 3. When an employee performs better than the } \\
\text { average level, my leader praises him/her. }\end{array}$ & 0.85 & 0.06 & 16.18 \\
\hline & $\begin{array}{l}\text { 4. When an employee works well, my leader } \\
\text { especially recognizes and praises him/her. }\end{array}$ & 0.64 & 0.06 & 10.58 \\
\hline & $\begin{array}{l}\text { 5. When an employee performs well, my leader } \\
\text { always gives him/her positive feedback. }\end{array}$ & 0.64 & 0.06 & 10.59 \\
\hline \multirow{7}{*}{$\begin{array}{l}\text { Authentic pride } \\
(\alpha=0.81, p<0.001)\end{array}$} & 1. I feel confident. & 0.67 & 0.07 & 11.34 \\
\hline & 2. I feel a sense of achievement. & 0.82 & 0.06 & 15.30 \\
\hline & 3. I feel I am valuable. & 0.89 & 0.05 & 17.47 \\
\hline & 4. I feel that I have achieved my goal. & 0.83 & 0.06 & 15.93 \\
\hline & 5. I feel that I am knowledgeable. & 0.66 & 0.05 & 11.63 \\
\hline & 6. I feel satisfied. & 0.83 & 0.06 & 15.27 \\
\hline & 7. I feel I am productive. & 0.76 & 0.05 & 13.77 \\
\hline \multirow{7}{*}{$\begin{array}{l}\text { Hubristic pride } \\
(\alpha=0.91, p<0.001)\end{array}$} & 8. I feel arrogant. & 0.48 & 0.05 & 8.18 \\
\hline & 9. I feel like I want to show off. & 0.71 & 0.04 & 13.12 \\
\hline & 10. I feel I am snobbish. & 0.85 & 0.04 & 16.98 \\
\hline & 11. I feel proud. & 0.93 & 0.03 & 19.99 \\
\hline & 12. I feel self-important. & 0.65 & 0.05 & 11.73 \\
\hline & 13. I feel self-righteous. & 0.89 & 0.03 & 18.49 \\
\hline & 14. I think highly of myself. & 0.89 & 0.04 & 18.38 \\
\hline \multirow{5}{*}{$\begin{array}{l}\text { Task performance } \\
(\alpha=0.84, p<0.001)\end{array}$} & 1. Adequately completes assigned duties. & 0.66 & 0.06 & 11.08 \\
\hline & $\begin{array}{l}\text { 2. Fulfills responsibilities specified in his/her } \\
\text { job description. }\end{array}$ & 0.73 & 0.06 & 12.60 \\
\hline & 3. Performs tasks that are expected of him/her. & 0.63 & 0.07 & 10.44 \\
\hline & $\begin{array}{l}\text { 4. Meets formal performance requirements of } \\
\text { the job. }\end{array}$ & 0.84 & 0.06 & 15.07 \\
\hline & $\begin{array}{l}\text { 5. Engages in activities that will directly affect } \\
\text { his/her performance evaluations. }\end{array}$ & 0.39 & 0.08 & 5.99 \\
\hline
\end{tabular}


Table 1. Cont.

\begin{tabular}{|c|c|c|c|c|}
\hline Variable & Item & $\begin{array}{l}\text { Standardized } \\
\text { Estimated }\end{array}$ & $\begin{array}{l}\text { Standard } \\
\text { Errors }\end{array}$ & Z (Est./S.E.) \\
\hline \multirow{10}{*}{$\begin{array}{c}\text { OCB } \\
(\alpha=0.86, p<0.001)\end{array}$} & $\begin{array}{l}\text { 1. If employees can't keep up with their work, } \\
\text { he/she will give help. }\end{array}$ & 0.85 & 0.06 & 16.90 \\
\hline & $\begin{array}{l}\text { 2. Willing to share his/her expertise with other } \\
\text { team members. }\end{array}$ & 0.82 & 0.05 & 15.81 \\
\hline & $\begin{array}{l}\text { 3. Try to be a mediator when other team } \\
\text { members disagree. }\end{array}$ & 0.38 & 0.07 & 6.17 \\
\hline & $\begin{array}{l}\text { 4. Take measures to try to avoid conflicts with } \\
\text { other team members. }\end{array}$ & 0.23 & 0.08 & 3.70 \\
\hline & $\begin{array}{l}\text { 5. Willing to spend time helping team members } \\
\text { who encounter problems at work. }\end{array}$ & 0.71 & 0.06 & 12.85 \\
\hline & $\begin{array}{l}\text { 6. Say hello to other team members in advance } \\
\text { before doing anything that may affect them. }\end{array}$ & 0.72 & 0.06 & 13.29 \\
\hline & $\begin{array}{l}\text { 7. Encourage other team members when they } \\
\text { are depressed. }\end{array}$ & 0.73 & 0.05 & 13.49 \\
\hline & $\begin{array}{l}\text { 8. Provide constructive suggestions on how to } \\
\text { improve team efficiency. }\end{array}$ & 0.68 & 0.07 & 12.11 \\
\hline & $\begin{array}{l}\text { 9. Willing to risk dissatisfaction and express } \\
\text { their best views on the team. }\end{array}$ & 0.38 & 0.07 & 6.22 \\
\hline & $\begin{array}{l}\text { 10. Participate in and actively participate in } \\
\text { team meetings. }\end{array}$ & 0.69 & 0.06 & 12.32 \\
\hline
\end{tabular}

To test the hypotheses of main effect and mediating effect, we adopted the stepwise regression method by SPSS20.0. To test the moderated mediating effect, the PROCESS macro module in SPSS20.0 was used.

\section{Results}

Descriptive statistical analysis can help to extract the demographic characteristics of the respondents in the sample. In this study, the collected sample data were statistically analyzed, and the descriptive statistics in Table 2 were obtained. Among the 268 samples, 140 were male $(52.24 \%)$ and 128 were female $(47.76 \%)$; the average age was 30.62 years old $(\mathrm{SD}=27.72)$, and most of them were $26-40$ years old, accounting for $77.20 \%$; the highest education level was mainly a bachelor's degree and master's degree, accounting for $86.6 \%$; there was no significant difference between unmarried $(42.54 \%)$ and married $(57.46 \%)$ individuals. The average working time was $43.8 \mathrm{~h}$ per week $(\mathrm{SD}=45.93)$.

Table 2. Descriptive statistical analysis $(\mathrm{N}=268)$.

\begin{tabular}{cccc}
\hline Characteristics & Option & Frequency & Percentage \\
\hline \multirow{2}{*}{ Gender } & Man & 140 & $52.24 \%$ \\
& Woman & 128 & $47.76 \%$ \\
Age & $21-25$ years old & 36 & $13.43 \%$ \\
& $26-30$ years old & 126 & $47.01 \%$ \\
& $31-40$ years old & 95 & $35.45 \%$ \\
& $41-50$ years old & 11 & $4.10 \%$ \\
\multirow{2}{*}{ Education } & High school and below & 2 & $0.75 \%$ \\
& Junior college & 34 & $12.69 \%$ \\
& Undergraduate & 172 & $64.18 \%$ \\
Marriage & Master or above & 60 & $22.39 \%$ \\
& Unmarried & 114 & $42.54 \%$ \\
& Married & 154 & $57.46 \%$ \\
\hline
\end{tabular}

Means, SDs, and intercorrelations among study variables are reported in Table 3. Intercorrelation analysis provided us with preliminary evidence of the relationship between variables and provided support for subsequent tests. The CFA results were shown in 
Table 4. The four-factor model fits the data well, supporting the distinctiveness of our study variables.

Table 3. Means, SDs, and intercorrelations among study variables.

\begin{tabular}{|c|c|c|c|c|c|c|}
\hline Variables & Mean & SD & Employee Recognition & Authentic Pride & Hubristic Pride & Task Performance \\
\hline Employee Recognition & 3.24 & 0.66 & & & & \\
\hline Authentic Pride & 3.95 & 0.65 & $0.20 * *$ & & & \\
\hline Hubristic Pride & 1.63 & 0.66 & 0.01 & $-0.13 *$ & & \\
\hline Task Performance & 5.29 & 0.81 & $0.14 *$ & $0.22 * *$ & -0.04 & \\
\hline OCB & 5.23 & 0.75 & $0.16 *$ & $0.21 * *$ & -0.06 & $0.56^{* *}$ \\
\hline
\end{tabular}

Note: $\mathrm{N}=268 .{ }^{*} p<0.050,{ }^{* *} p<0.010$.

Table 4. Confirmatory Factor Analysis.

\begin{tabular}{ccccccc}
\hline & $\chi^{2} / \mathbf{d f}$ & RMSEA & NFI & IFI & TLI & CFI \\
\hline Four-factor model (OCB) & 1.79 & 0.07 & 0.83 & 0.90 & 0.88 & 0.91 \\
Four-factor model (TP) & 1.82 & 0.07 & 0.81 & 0.88 & 0.87 & 0.89 \\
Three-factor model & 2.39 & 0.10 & 0.70 & 0.72 & 0.72 & 0.77 \\
Two-factor model & 3.58 & 0.13 & 0.58 & 0.63 & 0.55 & 0.62 \\
One-factor model & 3.98 & 0.14 & 0.50 & 0.56 & 0.48 & 0.53 \\
\hline
\end{tabular}

Note: ER is employee recognition, AP is authentic pride, HP is hubristic pride, TP is task performance, and OCB is organizational citizenship behavior. Four-factor model (ER, AP, HP, TP; ER, AP, HP, OCB). Three-factor model (ER, $\mathrm{AP}+\mathrm{HP}$, TP + OCB). Two-factor model (ER + AP + HP, TP + OCB). One-factor model (ER + AP + HP + TP + OCB).

Table 5 showed the hypotheses testing results of task performance. Model 1 is the main effect regression of employee recognition with task performance. Model 2 is the mediating effect, adding the mediator, authentic pride, into Model 1 . Table 6 shows the hypotheses testing results of OCB. Model 3 is the main effect, and Model 4 is the mediating effect.

Table 5. Hypotheses Testing of Task Performance.

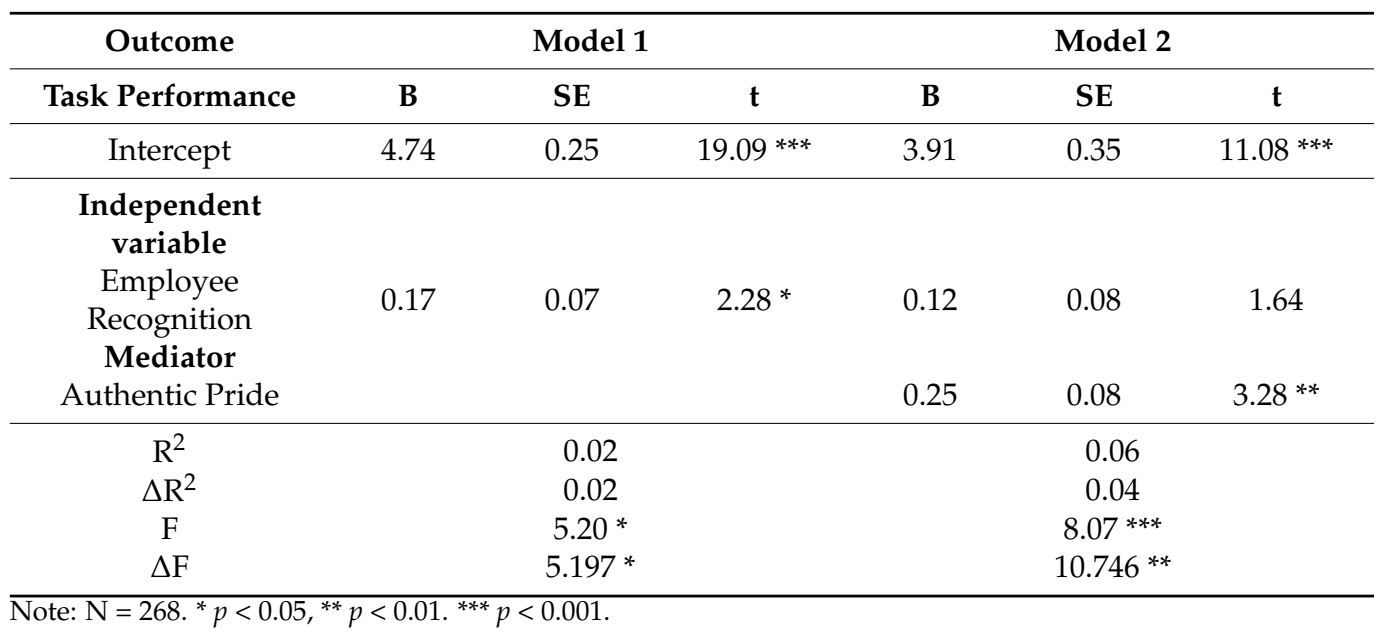

Hypothesis 1 proposed that employee recognition is positively related to task performance and OCB. As presented in Tables 5 and 6 , the main effect of employee recognition was significantly positively related to task performance $(B=0.17, p<0.05)$ and $O C B(B=0.18$, $p<0.01)$. Hypothesis 1 was supported. Hypothesis 2 predicted that authentic pride would mediate the relationship between employee recognition with (a)task performance and (b)OCB, mediated by hubristic pride. For high hubristic pride, the mediated relationship will be positive, while for low hubristic pride the relationship will be negative. The results in Tables 4 and 5 show the mediating effects of authentic pride in the path of employee recognition and task performance $(B=0.22, p<0.01)$, and of employee recognition and OCB $(B=0.25, p<0.01)$, which were both significant. Hypothesis 2 was supported. As 
in Table 7, the indirect effect of employee recognition on task performance via authentic pride was stronger at higher levels of hubristic pride (indirect effect $=0.08 ; 95 \% \mathrm{CI}(0.02$, 0.12)). As in Table 8, the indirect effect of employee recognition on OCB via authentic pride was stronger at higher levels of hubristic pride (indirect effect $=0.07 ; 95 \% \mathrm{CI}(0.012,0.15)$ ). Therefore, Hypothesis 3 is supported.

Table 6. Hypotheses Testing of OCB.

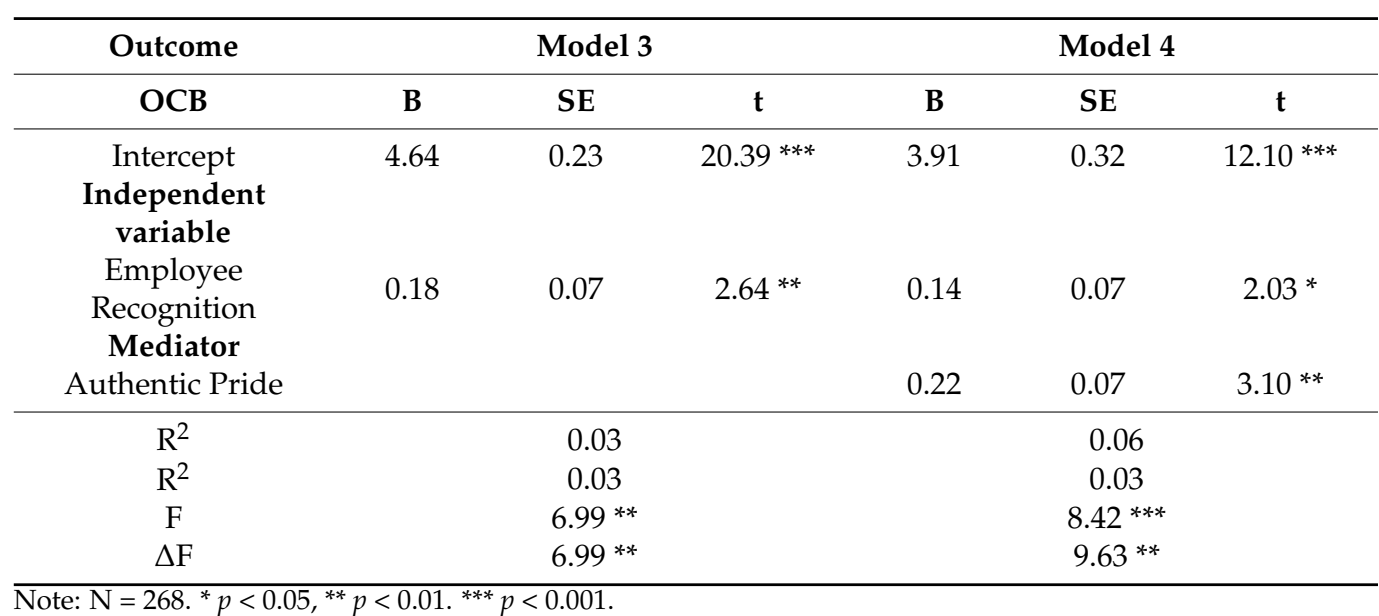

Table 7. Conditional indirect effect between employee recognition and task performance.

\begin{tabular}{cccccc}
\hline $\begin{array}{c}\text { Outcome } \\
\text { Task Performance }\end{array}$ & Hubristic Pride & B & Boot SE & \multicolumn{2}{c}{ 95\% Confidence Level } \\
\cline { 4 - 6 } Indirect effect & & & & & Lower \\
Low & 0.98 & 0.02 & 0.02 & -0.01 & 0.08 \\
Middle & 1.63 & 0.05 & 0.02 & 0.02 & 0.11 \\
High & 2.29 & 0.08 & 0.04 & 0.02 & 0.12 \\
\hline
\end{tabular}

Note: $\mathrm{N}=268$. Bootstrapping times $=5000$.

Table 8. Conditional indirect effect between employee recognition and OCB.

\begin{tabular}{cccccc}
\hline $\begin{array}{c}\text { Outcome } \\
\text { OCB }\end{array}$ & Hubristic Pride & B & Boot SE & \multicolumn{2}{c}{ 95\% Confidence Level } \\
\cline { 4 - 6 } & & & & Lower & Upper \\
\hline Indirect effect & 0.98 & 0.02 & 0.02 & -0.01 & 0.07 \\
Low & 1.63 & 0.04 & 0.02 & 0.01 & 0.09 \\
Middle & 2.29 & 0.07 & 0.03 & 0.02 & 0.15 \\
High & & & & & \\
\hline
\end{tabular}

Note: $\mathrm{N}=268$. Bootstrapping times $=5000$.

\section{Conclusions and Discussion}

\subsection{Research Findings}

Employee recognition is widely used in organizations [51]. Current studies have showed that employee recognition helps to reduce negative organizational outcomes, such as withdrawal and counterproductive work behaviors, and increases employees' wellbeing, strengthens their sense of organizational belonging, and improves organizational commitment and job satisfaction [52,53]. This study proves that employee recognition can lead to employee pride and promote employees to have better task performance and more organizational citizenship behaviors, which showed that recognition could be both positively related to in-role and out-role performance. These results are consistent with previous studies, and further enrich the recognition study.

Besides, pride, the two-facet construct, plays different roles in the organizational context. In recent years, pride has attracted more and more attention, and researchers have 
found different and even contradictory conclusions. Some believe that pride is associated with positive behavior and results $[54,55]$. Some believe that positive emotions may not produce positive outcomes, and may even be negative [56,57]. Integrating two-facet pride, how emotion functions is better understood. Authentic pride as a mediator mediates the positive relationship between employee recognition with task performance and OCB. Hubristic pride, as a moderator, moderates the indirect effect. While it is high, the relationship is much stronger. Results are all supported by the questionnaire data, which provides strong practical evidence. It is an interesting and meaningful perspective, that this study integrates pride with leadership behavior, considering two facets, emphasizing the importance of pride in the workplace, combined with the broaden-and-build theory of positive psychology.

\subsection{Theoretical and Practical Contributions}

This study has several theoretical contributions. Firstly, this study proved that employee recognition has a positive impact on task performance and OCB. This provided new materials and support for employee recognition research. Task performance and OCB were chosen as typical in-role and extra-role performance of employees. The results confirmed that employee recognition is beneficial to both of them, which revealed its importance and significance in organizational management practices.

Second, pride, divided into authentic pride and hubristic pride, plays a dual role in the pathway of employee recognition with task performance and OCB. This enriches the topic of emotion research in the field of organizational behavior. At present, emotion research in organization studies is no longer scarce and novel, but many cutting-edge analyses point out that emotion is a rich and changeable concept. For example, mainstream emotion studies tend to arbitrarily divide emotions into positive and negative categories, and consider their functions generally, which is a lack of research on the connotation and effect of discrete emotions [58]. Our study contributes to pride emotion research.

In addition to the theoretical contributions above, this study also has considerable practical significance. As a common approach to inspiring employees, employee recognition is favored by organizations and leaders because of its low economic cost and convenient operability. Leaders recognize and praise employees, their work behaviors, and results through oral praise, thank-you letters, emails, etc., which is helpful to stimulate employees positive emotions and emotional responses to work. Supervisors could use it to both pursue task performance and OCBs. This study reinsured that employee recognition as an important means of leadership practice and has positive effects directly linked to task performance. Besides this kind of in-role performance, employee recognition enables employees to show more OCBs. That is to say, supervisor recognition is also meaningful to extra-role performance. Through the exploration of employee recognition, this study provides a reference for leaders and managers, to give full play to the effect of this practice and show the charm of leadership. In addition, emotion in the workplace is an important factor that cannot be ignored [59]. In this study, pride turned out to be a positive function in the relationship of employee recognition with task performance and OCB. Authentic pride is a mediator, mediating the relationship between employee recognition with task performance and OCB. Hubristic pride is a moderator of this indirect relationship and positively moderates this mediation. Managers should be good at inspiring and arousing employees' positive emotions, creating a positive emotional culture [60].

\subsection{Limitations and Future Directions}

The contributions of this research should be considered in light of its limitations.

Firstly, we use the method of leader-member paired questionnaires, which caused several problems. The questionnaire needed participants to call recognition behaviors and their emotional response to mind when they answered the questionnaires. Memory may not be as reliable as we assumed, because it could change with time, which would lead to inaccurate results. To solve this problem, we chose correct and clear language 
expression in the questionnaire design from the start, and before the participants answered the questionnaire, we affirmed to them that they should answer according to the first intuition as to avoid possible post-processing. Finally, while selecting the questionnaires, all the unqualified results were eliminated. Nonetheless, we encourage future scholars to choose more scientific and reasonable research methods, such as the diary recording method, event triggering method, etc., to explore further.

Secondly, about the concept of pride, scholars believe that it is not only an emotion but also a kind of character. In this study, we focused on employees' emotional responses. We believe that although emotions are present and transient, they do have far-reaching effects on people. Besides, we think that pride as a trait is also an interesting research topic. Now studies have confirmed that the pride trait positively relates to creativity, performance, and achievements [19]. It will be great if future studies could do more research on pride, either as an emotion or as a trait.

Author Contributions: Conceptualization: T.Y.; methodology: T.Y.; software: T.Y.; validation: T.Y.; formal analysis: T.Y.; investigation: T.Y.; resources: T.Y.; data curation: T.Y.; writing—original draft preparation: T.Y. and X.J.; writing-review and editing: T.Y., X.J. and H.C.; project administration: T.Y. All authors have read and agreed to the published version of the manuscript.

Funding: This research received no external funding.

Institutional Review Board Statement: The study was conducted according to the guidelines of the Declaration of Helsinki and following academic ethics.

Informed Consent Statement: Written informed consent has been obtained from the participants to publish this paper.

Data Availability Statement: Not applicable.

Acknowledgments: We would like to thank all data providers and friends for their kind help.

Conflicts of Interest: The authors declare no conflict of interest.

\section{References}

1. Luthans, K. Recognition: A Powerful, but often Overlooked, Leadership Tool to Improve Employee Performance. J. Leadersh. Stud. 2000, 7, 31-39. [CrossRef]

2. Frey, B.S.; Neckermann, S. Awards: A View from Psychological Economics. J. Psychol. 2008, 216, 198-208. [CrossRef]

3. Van Woerkom, M.; Kroon, B. The Effect of Strengths-Based Performance Appraisal on Perceived Supervisor Support and the Motivation to Improve Performance. Front. Psychol. 2020, 11, 1883. [CrossRef]

4. Brun, J.-P.; Dugas, N. An analysis of employee recognition: Perspectives on human resources practices. Int. J. Hum. Resour. Manag. 2008, 19, 716-730. [CrossRef]

5. Tetrick, L.E.; Haimann, C.R. Employee recognition. In Workplace Well-Being: How to Build Psychologically Healthy Workplaces Day; Kelloway, E.K., Ed.; Wiley Blackwell: West Sussex, UK, 2014; pp. 161-174.

6. $\quad$ Eisenberger, R.; Karagonlar, G.; Stinglhamber, F.; Neves, P.; Becker, T.E.; Gonzalez-Morales, M.G.; Steiger-Mueller, M. Leadermember exchange and affective organizational commitment: The contribution of supervisor's organizational embodiment. $J$. Appl. Psychol. 2010, 95, 1085-1103. [CrossRef]

7. Cannon, M. Employee Recognition: Understanding the Construct, Its Measurement and Its Relationship to Employee Outcomes. Ph.D. Thesis, Saint Mary's University, Halifax, NS, Canada, 2015.

8. Gilbert, S.L.; Kelloway, E.K. Leadership, Recognition and Well-Being: A Moderated Mediational Model. Can. J. Adm. Sci. Rev. Can. Sci. l'Administration 2018, 35, 523-534. [CrossRef]

9. Montani, F.; Boudrias, J.-S.; Pigeon, M. Employee recognition, meaningfulness and behavioural involvement: Test of a moderated mediation model. Int. J. Hum. Resour. Manag. 2017, 31, 356-384. [CrossRef]

10. Lazarus, R.S. Cognition and motivation in emotion. Am. Psychol. 1991, 46, 352-367. [CrossRef]

11. Lewis, M.; Havilandjones, J.M.; Barrett, L.F. (Eds.) Handbook of Emotions, 3rd ed.; Guilford Press: New York, NY, USA, 2008.

12. Scheff, T. Goffman on Emotions: The Pride-Shame System. Symb. Interact. 2013, 37, 108-121. [CrossRef]

13. Kraemer, T.; Gouthier, M.H. How organizational pride and emotional exhaustion explain turnover intentions in call centers. $J$. Serv. Manag. 2014, 25, 125-148. [CrossRef]

14. Theobald, M.; Breitwieser, J.; Murayama, K.; Brod, G. Achievement emotions mediate the link between goal failure and goal revision: Evidence from digital learning environments. Comput. Hum. Behav. 2021, 119, 106726. [CrossRef]

15. Tracy, J.L.; Robins, R.W. The psychological structure of pride: A tale of two facets. J. Pers. Soc. Psychol. 2007, 92, 506-525. [CrossRef] 
16. Tracy, J.L.; Robins, R.W. The prototypical pride expression: Development of a nonverbal behavior coding system. Emotion 2007, 7, 789-801. [CrossRef]

17. Tracy, J.L.; Robins, R.W.; Schriber, R.A. Development of a FACS-verified set of basic and self-conscious emotion expressions Emotion 2009, 9, 554-559. [CrossRef]

18. Shi, Y.; Chung, J.M.; Cheng, J.T.; Tracy, J.L.; Robins, R.W.; Chen, X.; Zheng, Y. Cross-cultural evidence for the two-facet structure of pride. J. Res. Pers. 2015, 55, 61-74. [CrossRef]

19. Damian, R.I.; Robins, R.W. Aristotle's virtue or Dante's deadliest sin? The influence of authentic and hubristic pride on creative achievement. Learn. Individ. Differ. 2013, 26, 156-160. [CrossRef]

20. Costello, T.H.; Unterberger, A.; Watts, A.L.; Lilienfeld, S.O. Psychopathy and Pride: Testing Lykken's Hypothesis Regarding the Implications of Fearlessness for Prosocial and Antisocial Behavior. Front. Psychol. 2018, 9, 185. [CrossRef]

21. Peterson, S.J.; Luthans, F. The impact of financial and nonfinancial incentives on business-unit outcomes over time. J. Appl. Psychol. 2006, 91, 156-165. [CrossRef]

22. Pichler, S. The social context of performance appraisal and appraisal reactions: A meta-analysis. Hum. Resour. Manag. 2012, 51, 709-732. [CrossRef]

23. Pichler, S.; Beenen, G.; Wood, S. Feedback frequency and appraisal reactions: A meta-analytic test of moderators. Int. J. Hum. Resour. Manag. 2018, 31, 2238-2263. [CrossRef]

24. Kamdar, D.; McAllister, D.J.; Turban, D.B. "All in a Day's Work": How Follower Individual Differences and Justice Perceptions Predict OCB Role Definitions and Behavior. J. Appl. Psychol. 2006, 91, 841-855. [CrossRef]

25. Friedman, A.; Carmeli, A.; Dutton, J.E. When does respectful engagement with one's supervisor foster help-seeking behaviors and performance? J. Vocat. Behav. 2018, 104, 184-198. [CrossRef]

26. Basit, A.A. Examining how respectful engagement affects task performance and affective organizational commitment. Pers. Rev. 2019, 48, 644-658. [CrossRef]

27. Van Woerkom, M.; Meyers, M.C. Strengthening personal growth: The effects of a strengths intervention on personal growth initiative. J. Occup. Organ. Psychol. 2018, 92, 98-121. [CrossRef]

28. Meyers, M.C.; Kooij, D.; Kroon, B.; De Reuver, R.; Van Woerkom, M. Organizational Support for Strengths Use, Work Engagement, and Contextual Performance: The Moderating Role of Age. Appl. Res. Qual. Life 2019, 15, 485-502. [CrossRef]

29. van Woerkom, M.; Meyers, M.C.; Bakker, A.B. Considering strengths use in organizations as a multilevel construct. Hum. Resour. Manag. Rev. 2020, 100767. [CrossRef]

30. Adil, A.; Kausar, S.; Ameer, S.; Ghayas, S.; Shujja, S. Impact of organizational socialization on organizational citizenship behavior: Mediating role of knowledge sharing and role clarity. Curr. Psychol. 2021, 1-9. [CrossRef]

31. Vilela, B.B.; González, J.A.V.; Ferrín, P.F. Person-organization fit, OCB and performance appraisal: Evidence from matched supervisor-salesperson data set in a Spanish context. Ind. Mark. Manag. 2008, 37, 1005-1019. [CrossRef]

32. Kloutsiniotis, P.V.; Mihail, D.M. The effects of high performance work systems in employees' service-oriented OCB. Int. J. Hosp. Manag. 2020, 90, 102610. [CrossRef]

33. Tremblay, M.; Gaudet, M.-C.; Vandenberghe, C. The role of group-level perceived organizational support and collective affective commitment in the relationship between leaders' directive and supportive behaviors and group-level helping behaviors. Pers. Rev. 2019, 48, 417-437. [CrossRef]

34. Gouthier, M.H.; Rhein, M. Organizational pride and its positive effects on employee behavior. J. Serv. Manag. 2011, 22, 633-649. [CrossRef]

35. Mas-Machuca, M.; Berbegal-Mirabent, J.; Alegre, I. Work-life balance and its relationship with organizational pride and job satisfaction. J. Manag. Psychol. 2016, 31, 586-602. [CrossRef]

36. Elfenbein, H.A. 7 Emotion in Organizations. Acad. Manag. Ann. 2007, 1, 315-386. [CrossRef]

37. Williams, L.A.; DeSteno, D. Pride and perseverance: The motivational role of pride. J. Pers. Soc. Psychol. 2008, 94, 1007-1017. [CrossRef]

38. Ng, T.W.H.; Yam, K.C.; Aguinis, H. Employee perceptions of corporate social responsibility: Effects on pride, embeddedness, and turnover. Pers. Psychol. 2019, 72, 107-137. [CrossRef]

39. Gilchrist, J.D.; Conroy, D.E.; Sabiston, C.M. Experienced and Anticipated Pride and Shame as Predictors of Goal-Directed Behavior. J. Sport Exerc. Psychol. 2017, 39, 438-442. [CrossRef] [PubMed]

40. Tsachouridi, I.; Nikandrou, I. Organizational virtuousness and spontaneity: A social identity view. Pers. Rev. 2016, 45, 1302-1322. [CrossRef]

41. Fredrickson, B.L.; Branigan, C. Positive Emotion; The Guilford Press: New York, NY, USA, 2005.

42. Fredrickson, B.L. Love 2.0: How Our Supreme Emotion Affects Everything We Feel, Think, Do, and Become; Hudson Street Press: New York, NY, USA, 2013.

43. Fredrickson, B.L.; Cohn, M.A.; Coffey, K.A.; Pek, J.; Finkel, S.M. Open hearts build lives: Positive emotions, induced through loving-kindness meditation, build consequential personal resources. J. Pers. Soc. Psychol. 2008, 95, 1045-1062. [CrossRef] [PubMed]

44. Hirak, R.; Peng, A.C.; Carmeli, A.; Schaubroeck, J. Linking leader inclusiveness to work unit performance: The importance of psychological safety and learning from failures. Leadersh. Q. 2012, 23, 107-117. [CrossRef]

45. Ashkanasy, N.M.; Dorris, A. Emotions in the Workplace. Annu. Rev. Organ. Psychol. Organ. Behav. 2017, 4, 67-90. [CrossRef] 
46. Salerno, A.; Laran, J.; Janiszewski, C. Pride and Regulatory Behavior: The Influence of Appraisal Information and Self-Regulatory Goals. J. Consum. Res. 2015, 42, 499-514. [CrossRef]

47. Walumbwa, F.O.; Wu, C.; Orwa, B. Contingent reward transactional leadership, work attitudes, and organizational citizenship behavior: The role of procedural justice climate perceptions and strength. Leadersh. Q. 2008, 19, 251-265. [CrossRef]

48. Waldman, D.A.; Bass, B.M.; Yammarino, F.J. Adding to Contingent-Reward Behavior. Group Organ. Stud. 1990, 15, 381-394. [CrossRef]

49. Methot, J.R.; Lepine, J.A.; Podsakoff, N.P.; Christian, J.S. Are Workplace Friendships a Mixed Blessing? Exploring Tradeoffs of Multiplex Relationships and their Associations with Job Performance. Pers. Psychol. 2015, 69, 311-355. [CrossRef]

50. Bachrach, D.G.; Wang, H.; Bendoly, E.; Zhang, S. Importance of Organizational Citizenship Behaviour for Overall Performance Evaluation: Comparing the Role of Task Interdependence in China and the USA. Manag. Organ. Rev. 2007, 3, 255-276. [CrossRef]

51. Garr, S.S. The State of Employee Recognition in 2012; Bersin \& Associates: Oakland, CA, USA, 2012.

52. Bradler, C.; Dur, R.; Neckermann, S.; Non, A. Employee Recognition and Performance: A Field Experiment. Manag. Sci. 2016, 62, 3085-3099. [CrossRef]

53. Long, R.J.; Shields, J.L. From pay to praise? Non-cash employee recognition in Canadian and Australian firms. Int. J. Hum. Resour. Manag. 2010, 21, 1145-1172. [CrossRef]

54. Bagozzi, R.P.; Sekerka, L.E.; Sguera, F. Understanding the consequences of pride and shame: How self-evaluations guide moral decision making in business. J. Bus. Res. 2018, 84, 271-284. [CrossRef]

55. Hwang, K.; Lee, B. Pride, mindfulness, public self-awareness, affective satisfaction, and customer citizenship behaviour among green restaurant customers. Int. J. Hosp. Manag. 2019, 83, 169-179. [CrossRef]

56. van Osch, Y.; Zeelenberg, M.; Breugelmans, S.M.; Brandt, M.J. Show or hide pride? Selective inhibition of pride expressions as a function of relevance of achievement domain. Emotion 2019, 19, 334-347. [CrossRef]

57. Louro, M.J.; Pieters, R.; Zeelenberg, M. Negative Returns on Positive Emotions: The Influence of Pride and Self-Regulatory Goals on Repurchase Decisions. J. Consum. Res. 2005, 31, 833-840. [CrossRef]

58. Gooty, J.; Gavin, M.; Ashkanasy, N.M. Emotions research in OB: The challenges that lie ahead. J. Organ. Behav. 2009, 30, 833-838. [CrossRef]

59. Bono, J.E.; Foldes, H.J.; Vinson, G.; Muros, J.P. Workplace emotions: The role of supervision and leadership. J. Appl. Psychol. 2007, 92, 1357-1367. [CrossRef] [PubMed]

60. Men, L.R.; Yue, C.A. Creating a positive emotional culture: Effect of internal communication and impact on employee supportive behaviors. Public Relat. Rev. 2019, 45, 101764. [CrossRef] 